\title{
The Future of New Zealand's National Superannuation
}

\author{
David Thomson
}

$\mathrm{F}$ ROM its first mooting in 1975, national superannuation in New Zealand has attracted heated debate and frequent amendment. This intensified in the late 1980 s, as first a Labour government and then a National government sought to lower personal expectations, cut costs to government, and avoid a backlash. Since 1993, exhaustion with pension issues, an uneasy silence and widespread avoidance of the unpalatable have become apparent. The government insists that the changes necessary to sccure 'fiscal sustainability' have now been made, and most New Zealanders want to believe it. The significant political parties have agreed since mid-1993 to a cross-party Superannuation Accord, under which they agree to speak on superannuation issues with onc voice, and, if possible, not to speak on them at all.

\section{The Reform Flurry}

At its outset in 1977, national superannuation ${ }^{1}$ provided a universal taxable payment from age 60, without incomes or assets tests, for all who had resided in New Zealand for ten or more years. Gross weekly payments to an elderly married couple were equal to 80 per cent of the gross average wage, and the scheme was cited widely as perhaps the most generous anywhere. State income support for the aged doubled to about 8 per cent of GDP, and talk of old-age poverty was replaced by concerns with 'affordability'. These were heightened from the late 1970 s by widening government budget deficits, mounting public debt, and growing awareness of the ageing of the population.

Even so, reform came slowly. From 1979 superannuation payments were linked to net rather than gross wages, and from 1985 a surcharge - in effect a limited incomes test through the tax system - was imposed upon the higher-income elderly. This was intensely unpopular with many of the aged, though only about one-quarter

\footnotetext{
${ }^{1}$ Two excellent surveys of superannuation in New Zcaland are Ashton and St John (1988) and St John and Ashton (1993). This article draws heavily upon these studies.

${ }^{2}$ Each elder continues to reccive national superannuation, but, once 'other income' passes a certain point, the special charge applies in addition to nommal rates of income tax, until all of the national superannuation has been taken back: thereafter standard income tax rates apply once more to any further income. The surcharge is, therefore, not an open-ended surtax levied on all income beyond a set level.
}

David Thomson is Associate Professor of History at Massey University. 
have any part of their national superannuation clawed back by the surcharge. Neither reform did much to reduce costs or to allay a growing sense that more radical reform had become imperative.

In 1987 the Labour government began very gingerly to prod debate, for example with a large scale Royal Commission on Social Policy (1988) and with discussion booklets to every home (Department of Social Welfare, 1988, 1989). There followed about five years of acrimonious debate and faltering reform, resulting in three major decisions. First, the tax surcharge has been retained despite widespread unease among politicians over this potential electoral liability. At its election in 1984 Labour undertook not to alter national superanmuation significantly, and the introduction of the surcharge within a few months aroused loud and lasting charges of betrayal. During the 1990 election campaign Jim Bolger's National Party promised to do away with the surcharge. But in their mid-1991 budget they linked abolition with a new and more stringent incomes test for national superannuation. A campaign by elder groups, together with threats of defection by backbench MPs and growing evidence on the impracticalities of the new plans, led to their being abandoned in late 1991. The surcharge was kept, although with lowered income exemptions and a higher rate of clawback.

Second, the age of eligibility has been raised. The low age of 60 years had long dismayed those responsible for balancing budgets; one of the Labour government's pamphlets opened with the insistence that 'Quite simply, we cannot afford to continue with our current national superannuation scheme' (Department of Social Welfare, 1989). Labour proposed in 1989 to raise pension age, very slowly and well into the future, from 60 to 65 years. The changes would not begin until 2006 , or be fully effective until 2026. The plan aroused little popular anguish, and served to establish 65 rather than 60 as the 'correct' pensionable age. In 1991 the National government announced a ten-year transition to age 65 , to begin at once. Those in their fifties or early sixties who were caught out by the accelerated transition were to fall back on the standard unemployment benefits, which at that moment were being cut substantially. The hastened transition to age 65 was widely accepted, became part of the 1993 Accord, and is now under way. An easing of unemployment benefits for those aged 55 to 64 was part of the price of cross-party agreement.

Third, the linkage between wages, prices and national superanmuation has been loosened. Until 1988, net rates of superannuation had been tied to net average ordinary time wages, with twice-yearly adjustments. From 1989, adjustments became annual, and so introduced a small lag in the climb of weekly superannuation rates. More important, adjustment was now in step with the lesser of either net wage or price movements. The intention was a slow fall in relative worth, until national superannuation for a married couple was down to 65-72 per cent of net average wages. As part of its 'anti-welfare' budget of mid-1991, the National government pushed the deindexing harder. There was to be no indexing at all during 1991 and 1992, and thereafter national superamuation was to settle towards the 65 per cent figure.

As these changes were being made, New Zealanders renewed an old debate about private superannuation as an alternative to public dependence in old age. This had 
first been mooted in the $1880 \mathrm{~s}$, well before state pensions were introduced, but had been rejected as impracticable and inequitable then and at each point thereafter. The one brief exception occurred in the mid-1970s, when for a few months the short-lived Kirk Labour government established a compulsory universal state superannuation savings scheme. It helped Labour lose the 1975 election and was abandoned at once. It continues to cloud all discussion of funded superannuation and compulsory savings in New Zealand, where voters remain wary of shifting the costs of old age from the state and taxpayers to private insurers and individual savers.

\section{The Todd Reports}

The most focused exploration of these issues occurred in 1991-92, following the appointment of a Task Force on Private Provision for Retirement under the chairmanship of Jeff Todd. Its reports (1991, 1992a, 1992b) attracted wide attention, yet seem to have changed few minds. The Todd group chose not to push a reforming agenda, but to seek and then to promote a national consensus on retirement income. Their modest recommendations were to retain universal state provision and the surcharge, accept the reduced benefit levels and raised entitlement ages already in train, shun compulsory saving, and provide only limited encouragement for top-up private superannuation savings. This stance was also accepted into the Accord.

A further recommendation, also accepted, was 'no change' on the vexed question of income-tax relief for superannuation savers. For 70 years taxpayers enjoyed exemptions on life insurance and superamnuation contributions, while eventual benefits were taxed (unless taken as a lump sum). But from 1987 this was ended by Labour, on the grounds that exemptions unduly favoured affluent middle-class males, were not encouraging widespread superannuation membership, and were failing to boost national savings levels or economic growth. Since 1990 contributions to and eamings by superannuation schemes have been taxed in full, while benefits paid out have been tax-exempt. Among other things, this makes New Zealand stand alone among OECD nations. It led to a closing of many employer schemes, a scaling back of others, and falling membership.

\section{'Affordable' and 'Sustainable'?}

In the mid-1990s, then, New Zealand still has a universal, non-contributory national superannuation scheme, though it has been cut back considerably from the more gencrous program of the 1970s and 1980s. Age of entitlement is 62 and rising to 65, benefit levels are to ease down further relative to wages, and the more affluent minority repays some or all of its benefits through income tax. Additional private superannuation saving is undertaken by about half of the workforce, is voluntary and attracts no tax relief, and these arrangements are still the subject of cross-party agreement. Political leaders repeat that the current scheme is affordable; a desire to believe them and to leave the whole subject alone is widespread.

This naive wish will of course be defeated, since population structures, social patterns, global and internal economic arrangements, ideas about government, notions of 
responsibility to the old and more will all go on evolving. Nor can anyone bind future governments and voters, since there simply is no mechanism for doing so.

More specific forces will propel reassessment during the next few years. For one thing, important sections of the older population have not accepted the changes, and campaign against the surcharge in particular. More generally, a substantial minority of all ages opposes the broad policy shifts of the last decade, and politicians will always be sensitive to this and be tempted to trim accordingly.

Second, the Accord will go on being assailed by those who believe the reforms of the last few years are inadequate. They are many. Leaders of the superannuation industry regularly insist that saving for old age is far too low and must be made compulsory. The Todd group eschewed compulsion for now, but urged that periodic reviews of progress in expanding voluntary saving be undertaken and that compulsion remain a future option. The Retirement Commissioner, an office created following Todd recommendations with the task of fostering private saving, comments from time to time on a worrying failure in self-provision for old age. Examples from abroad, most obviously Australia's mandatory superannuation savings, will be observed and debated. And some political parties will push altenatives. The most significant of these just now is Roger Douglas's Association of Consumers and Taxpayers, which proposes compulsory individual superannuation savings accounts, with regular personal (not employer) contributions being required at least until a set sum (the initial suggestion was NZ\$122,500 in 1993 dollars) had been accumulated (Douglas, 1993).

These many pressures upon the Accord will be played out in fresh surroundings, for New Zealand is entering a now political and perhaps also a new budgetary era. From 1996, the country will be governed by more complex multiparty coalitions as a result of its new proportional representation electoral system. The need for compromise among governing parties may produce inertia on superamuation or an inability to move in any direction. In addition, a diversity of political voices may increase the clout of determined lobbies and voter blocks. The elderly could benefit from this, and some of the minor political parties have indicated that they will play for this vote.

New Zealand governments also look set to enjoy substantial budgetary surpluses for the first time in 20 or more years, and calls are already being heard to distribute these to the aged. There are many other competitors, of course: young families, lowand middle-income taxpayers, and holders of government debt. But I will be surprised if the elderly do not secure a portion of the new surpluses: indeed, the tax and benefit changes announced in late 1995 provide for small increases in the surcharge threshold in 1996 and 1997. (Of course, these so-called surpluses are illusory, given the public debt, run-down infrastructure and more that lie behind them.)

In brief, debate about superannuation will not stop. Iess clear is the path that this debate should take. The loudest voices for now are for more individual responsibility, private provision, compulsory savings, and funded rather than pay-as-you-go schemes. The arguments for these are both moral and economic: Roger Douglas (1993:155), for example, has claimed that greater savings for old age will improve incentives for cmployment, assist and reward effort, and, in a broader sense, self-help, participation and dignity ... [and] ensure that . . . economic growth is improved'. But these claims 
need to be tested. The case for a radical departure from national superannuation has not been established.

\section{The NZIER Report}

A good deal of the case for alternatives rests on assertions about the 'fiscal unsustainability' of national superannuation. Yet this claim received surprisingly little serious attention until the New Zealand Institute of Economic Research (NZIER, 1995) published the result of a study undertaken at the behest of the Retirement Commissioner. The authors conclude that national superannuation is fiscally sustainable through to 2050 without too much strain, given the assumptions fed into the model and given continued government resolve on restraining public expenditure and eliminating public debt over the next decade or so.

According to the Institute's 'central scenario', national superannuation costs will fall from a current 5.7 per cent of GDP to 4.5 per cent in 2000/01, then rise to 7.1 per cent in 2024/25 and 9.4 per cent in 2050/51. At the same time, public health costs (for persons of all ages) will rise from 5.6 per cent of GDP now to 8.0 per cent by $2024 / 25$ and to 10.3 per cent by $2050 / 51$. These increases are considerable, but by holding overall public expenditure growth and by using the next decade - before population ageing really bites — to repay all public debt, overall public expenditure might be held to 30 per cent of GDP by 2000/01, 33 per cent by $2024 / 25$, and $36-37$ per cent in 2050/51. In the view of the authors this is a sustainable cost.

Many of the assumptions must be open to challenge. Mortality, for instance, is assumed to be as projected by Statistics New Zealand, yet the experience of the last 25 years everywhere is that the aged are now far outlasting all estimates of their likely longevity, no matter how often these have been revised. Unemployment is assumed to stabilise to 4.3 per cent. Iabour-force participation is assumed to decline only modestly over the next century as the population ages; yet in recent decades in all countries the middle-aged have been ceasing paid work earlier and in increasing proportions, and this shows no signs of changing. Consumer price inflation over the next 50 years is held at a very optimistic 1 per cent a year; interest rates at just a little below current levels; and public expenditure increases remain in step with real economic growth at 1.8 per cent a year. No second-round effects are modelled: for example, of public spending as projected upon productivity or economic growth.

The authors are rightly cautious about all this, and note repeatedly the vulnerability of their model - and of New Zealand - to the unexpected economic downturn, to poor long-run economic performance, or to political softness in restraining expenditure or repaying debt. Still, it is a substantial study, and the onus must now be on the doomsayers to show that it is seriously wrong. Those wanting maintenance of the status quo can draw some support from this work.

\section{Alternatives to National Superannuation}

The economic viability of national superanmuation beyond about 2010 , then, remains open to debate. But so is that of other options. A second reason for caution about 
radical change now is that the favoured altematives - funded, private, compulsory have seldom been subjected to searching scrutiny such as that directed at public measures. There may be doubts about long-term state provision for old age. There are at least as many about the touted alternatives.

One central concern must be 'funding', or the notion that workers can somehow store away resources for their own futures. But savings or funded reserves do not somehow exist outside of the normal economy, to be called in as some deus ex machina when problems arise. They therefore do not really alter the fundamental distributional battles that must eventuate between old and young, though they may help ease or mask them - or embitter them further. A difficulty facing Northern Hemisphere governments as they scale back their public old-age pensions is that the language of personal savings contributions through life has given ageing citizens a false but stoutly defended sense that they have pre-paid for their own old age in a direct and inalienable way. It is one reason why some look with envy at the relative freedom to reform that countries like New Zealand enjoy, with their non-contributory pensions and broad-based tax to finance them: ${ }^{3}$ all New Zealandres know that old-age provision is and remains a direct matter of political decision of the moment. That can have its drawbacks, but also its advantages.

In other words, the retired claim, and will go on claiming, shares of the time and effort of their younger successors through superamuation schemes, interest on bank deposits, rents on houses, sale of property, sharing homes with children, running down assets, collecting state pensions, living in public institutions and many more. As the population ages rapidly, it is not clear that savings-based claims can or will or should be met ahead of others, or that saving through life will necessarily increase the overall share of resources that the society decides in 2030 or whenever is to be allocated to the aged. Pay-as-you-go redistribution is all there is and can ever be.

Moreover, 'funding', or the building of savings in either private pension or public social-security schemes, has a poor historical record as a means of providing for old age. It has not worked, even when the ratio of old to young was highly favourable to success, as it now cannot be again. Private savings have often disappointed because of poor investment decisions or outright fraud. Interest eamings on savings prove unpredictable and unreliable. Coverage of the population has usually been very patchy. Nor have private funds proven immune to subsequent interference and default. It is not the case that private (unlike public) savings are safe because protected by the laws of private property. In New Zealand and elsewhere in the $1930 \mathrm{~s}$, for instance, mortgage capital and interest cannings were unilaterally and permanently written down or wiped altogether by government decision. In the post-war era, financial regulation meant that savers did not get the returns they might have expected, or had contracted for with financial institutions, but whatever the government of the day decided. Changes in capital gains, property or death taxes, to the rules on lump-sum payments

\footnotetext{
${ }^{3}$ The advantages of this have been mooted, for example, by the OECD (1988a, 1988b) and the World Bank (1994).

${ }^{4}$ This is discussed further in Ashton and St John (1988) and St John and Ashton (1993).
} 
or on the interaction between state pension and private retirement incomes, are further examples of how returns on private savings are affected by political decisions all along the way. And over all of this lies inflation, which historically has destroyed or boosted returns on private savings to great and unpredictable degrees.

'Funded' public pension schemes, much favoured in post-war Europe, have also proven anything but reliable. Many so-called funded schemes were never in fact that, since constant pay-as-you-go subsidies from taxes on the later-bom were always anticipated from the outset. Social security funds, once they began to mount, were often tapped by governments for other purposes; the USA provides the outstanding recent example. More important, the amounts accumulated have fallen behind what is required to give the retired the benefits they have come to insist upon, which are now substantially greater than initially stipulated in those aged individuals' contracts with the funded schemes. Earlier-than-expected retirement and the unanticipated lengthening of life have added to the gap between funds and the income they generate, and the retirement payouts demanded. Inflation further weakened any semblance of an actuarial link between funds invested and benefits paid. What Northern Hemisphere populations have wanted in the 20th century was the fiction of funding - of 'having already paid personally for everything I get back' — and the right to have this funding history ignored if that suits better when benefit payments are calculated.

\section{Compulsion and Investment}

This record does not prove that saving or of pre-funded old-age provision for all is irrelevant or without value. It may be important to aged individuals' sense of selfworth. It may be vital to good bonds between generations, through easing some of the grosser income inequities between different birth cohorts that are emerging in the late 20th century. Saving for old age may, as the pundits have insisted through history, foster the work ethic, a spirit of self-help, responsibility and good citizenship.

Compulsory saving for old age may also increase overall national savings, and this may lead to more and better long-term investment, thence to greater future productivity, and thus improve society's ability and willingness later to repay today's savers with at least some of the consumption they have forgone. But the comnections are not automatic, as advocates of greater superaunuation savings seem to assume; and the history of the 20th century does not provide unambiguous demonstrations of strong linkages in practice. 'Moreover, if improved investment is the real objective of compulsory saving, then citizens need to know this and be treated honestly.

Indeed, improved investment has to be the true goal of all old age policy. Perhaps it can best be achieved under the guise of superammuation savings, or of letting people think or pretend that they are saving for their own personal futures rather than for that of society in general. But until there is more hard-headed assessment of the

\footnotetext{
5 See Thomson (1991:Ch. 1) and the references there on the fiction of funding. 6

A good example of ambivalence on this is World Bank (1994). Much of this massive report is concenned with the limitations of funded provision for old age and the lack of clear evidence on its capacities, yet the conclusion pushed throughout is that saving is the only viable route forward.
} 
purposes of, and of the risks inherent in, pushing large-scale saving for old age amid rapid population ageing, I suggest that New Zealand sticks for now with what it has: a tax-funded pay-as-you-go pension, together with opportunities for private saving in various forms. I suggest too that more realism and humility are due all round: it is not going to be possible to treat the elderly of next century with anything like the generosity shown to the elderly now, no matter what we try, and we had better start helping people to accept that. There are no escapes, or easy fixes: the chickens, unavoidably, are coming home to roost. All debate about old age takes place within that frame.

\section{References}

Ashton, T. \& S. St John (1988), Superannuation in New Zealand: Averting the Crisis, Institute of Policy Studies, Wellington.

Department of Social Welfare (1988), Income Security for the Elderly. Planning a Secure Future for All New Zealanders, Wellington.

- (1989), Guaranteed Retirement Income., Wellington.

Douglas, R. (1993), Unfinished Business, Random House, Auckland.

New Zealand Institute of Economic Research (NZIER) (1995), The Fiscal Impacts of an Aging PopuJation, Wellington.

Organization for Economic Cooperation and Development (OECD) (1988a), Ageing Populations: The Social Policy Implications, Paris.

— (1988b), Reforming Public Pcnsions: Background, Pressures and Options, Paris.

Royal Commission on Social Policy (1988), The April Report, Wellington.

St John, S. \& T. Ashton (1993), Private Pensions in New Zealand: Can They Avert The 'Crisis'? Institute of Policy Studies, Wellington.

Task Force on Private Provision for Retirement (1991), Private Provision for Retirement: The Issues, Wellington.

- (1992a), Private Provision for Retirement The Options, Wellington.

- (1992b), Private Provision for Retirement: The Way Forward, Wellington.

Thomson, D. (1991), Selfish Generations? The Ageing of New Zealand's Welfare State, Bridget Williams Books, Wellington.

World Bank (1994), Averting the Old Age Crisis: Policies to Protect the Old and Promote Growth, World Bank and Oxford University Press, New York. 